\title{
Utilization Avenues for Induced Pluripotent Stem Cells in Autism
}

\section{Uyarılmış Pluripotent Kök Hücrelerin Otizm’de Kullanım Alanları}

\author{
Ceymi Doenyas $^{1}$, Nelisa Türkoğlu Laçin ${ }^{2}$
}

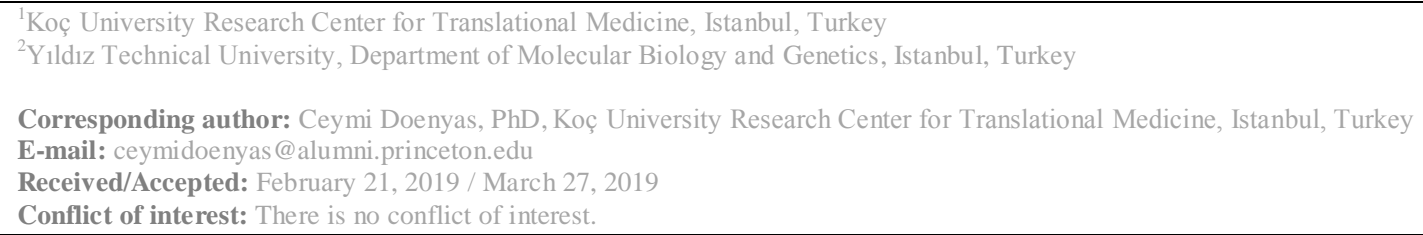

\section{SUMMARY}

Objective: Autism spectrum disorder (ASD) is a neurodevelopmental difference with increasing global prevalence. Yet, the etiology of ASD is still not unraveled. Individuals with ASD experience difficulties with social skills and communication, and exhibit repetitive and restrictive interests and behaviors.

Method: There is yet no comprehensive model of autism that can explain all aspects of autism. Similarly, there exists no known treatment for it. Induced pluripotent stem cell (iPSC), which has been widely used in the regenerative treatment of many diseases in recent years, is promising for a better understanding of the causes of autism.

Results: Autism modelling with iPSCs provides several opportunities for understanding the mechanisms underlying autism and developing personalized treatments.

Conclusions: This review examines the use of iPSCs in ASD to date, their advantages, and the findings obtained via iPSC modeling of autism.

Keywords: autism; induced pluripotent stem cell, modelling

\section{ÖZET}

Amaç: Otizm spektrum bozukluğu, dünya çapında yaygınlığı giderek artan fakat sebepleri hala tamamen bilinmeyen, nörogelişimsel bir farkl11ıktır. Otizmli bireyler, sosyal beceri ve iletişim zorlukları yaşarlar; tekrar eden ve kısıtlayıcı ilgi alanları ile davranışlar gösterirler. Otizmin bilinen bir tedavisi veya otizmin bütün unsurlarını açıklayabilen kapsamlı bir model henüz yoktur.

Yöntem: Son yıllarda birçok hastalığın rejeneratif tedavisinde oldukça yaygın olarak kullanılan kök hücrelerden, uyarılmış pluripotent kök hücre (UPKH), otizmin sebeplerinin daha iyi anlaşılması için umut vaat edicidir.

Bulgular: UPKH'ler ile yürütülen otizm modellemeleri, otizme neden olan mekanizmaların anlaşılması, bozuklukların düzeltilmesi ve kişiye özel tedavilerin geliştirilmesi için çeşitli firsatlar sunmaktadır.

Sonuç: Bu derleme, UPKH'lerin şu ana kadar otizmdeki kullanım alanlarını, avantajlarını ve UPKH modellemeleri ile elde edilen bulguları incelemektedir. 


\section{INTRODUCTION}

Autism spectrum disorder (ASD) is a developmental difference characterized by difficulties in social skills and communication, and repetitive and restrictive areas of interest and behavior, which affects 1 out of 59 individuals according to the most recent data ${ }^{1,2}$. Genetic and environmental factors play a role in the emergence of ASD. Nonetheless, autism is not a single gene defect; so far, none of the genes associated with ASD can account for more than $1 \%$ of cases of autism alone, making autism a multi-gene defect and complicating the discovery of treatments for it. Furthermore, the variety of environmental factors that constitute a risk factor for autism (e.g., exposed toxins and inflammatory illnesses experienced during pregnancy) make it difficult to find a single cause for autism. For these reasons, it is scientifically important to understand autism and find its treatment. To this end, this review presents the opportunities that can be offered for autism research by induced pluripotent stem cells (iPSCs), which have currently started gaining interest in the global scientific community. This paper overviews the recent disease modeling studies performed with iPSCs to better understand autism, and studies on iPSC models for the development of new generation approaches in the treatment of autism.

\section{Induced Pluripotent Stem Cells (iPSCs)}

Stem cells are self-renewing, non-specialized cells that can differentiate into specialized cells when they receive appropriate signals from their microenvironment ${ }^{3}$. Stem cells are classified according to their potency (number of possible fates for a cell). Totipotent stem cells are the cells formed starting from the period of zygote formation, which is the beginning of embryogenesis, and continuing until the blastocyst phase. Each of these cells has the potential to come to all fates in the human body, and has the ability to create the whole organism by themselves ${ }^{4}$. Pluripotent stem cells are cells derived from the inner cell mass during the blastocyst stage of the embryo, which have lost their full potency. These cells have the potency to form all cells originating from the ectoderm, endoderm, and mesoderm, but they cannot form an organism by themselves ${ }^{5}$. Multipotent stem cells are adult stem cells that can be differentiated into cells of only one of the ectoderm, endoderm, and mesoderm layers, and which can acquire many fates but not all fates. Oligopotent stem cells are cells that can acquire some fates.
Sometimes the multipotent and oligopotent concepts are used interchangeably in the field. Unipotent stem cells are stem cells that can be differentiated into a single cell type ${ }^{6}$.

Although totipotent and pluripotent stem cells have the potential to differentiate into almost all cells in the body, their use in scientific research and clinics is not possible due to ethical considerations regarding harvesting an embriyo.

A significant step towards overcoming these obstacles was made with the discoveries that brought the Nobel Prize to Gurdon and Yamanaka in 2012. It was demonstrated that somatic cells of an individual can be redifferentiated to a pluripotent stem cell by modifying some transcription factors. This method makes it possible to obtain pluripotent stem cells from an individual's somatic cells. In regenerative tissue engineering studies, it has been possible to use induced pluripotent stem cells obtained from the patient's own specialized cells for the treatment of damaged tissues and organs, without experiencing any compatibility problems ${ }^{7}$.

The capacity of iPSCs to differentiate into many different cell types has brought to consideration the use of these cells for disease modeling and drug screening studies. Research and clinical trials are underway for thereapeutic utilization of iPSCs in disorders of the eye, nervous system, heart, pancreas, liver, intestine, lung, circulatory system, and $\operatorname{skin}^{8}$.

Induced pluripotent stem cells do not only offer the possibility to understand and treat neurodegenerative disorders such as Alzheimer's, Parkinson's, and Amyotrophic Lateral Sclerosis', but can also be used to explore and treat neurodevelopmental disorders such as Timothy syndrome $^{10}$, schizophrenia, and autism ${ }^{11}$.

\section{Autism and iPSCs}

In disorders involving the human brain that comprises approximately 200 billion cells and has a highly complex structure, working with a brain model composed of pluripotent stem cells outside of the body instead is much more convenient and accelerates the acquisition of any results ${ }^{12}$. What is known to date about iPSC utilization in autism, which can serve both research and therapy 
purposes $^{13}$, is overviewed in the following sections.

\section{iPSCs in Autism Modelling}

To better understand autism, a condition associated with many genetic and environmental risk factors, iPSC-based modelling provides a more effective method than mouse and other animal models. The most widely used animal models for autism so far have been maternal immune activation (MIA) models that use different viruses on the pregnant mother and find the offspring to display all core symptoms of autism $^{14}$ and genetically modified BTBR mice that also display the autism symptoms ${ }^{15}$. Modelling with iPSC is more practical, faster, economical, and animal-friendly than mouse modeling. The contributions of these models to understanding autism have been as follows.

Firstly, it has been observed that many environmental and genetic factors associated with autism affect similar embryonic developmental processes. Namely, environmental and genetic factors seem to both have effects on the proliferation, migration, and differentiation of cells in the cerebral cortex. The utilization of iPSC-derived neural precursor cells can be a wonderful option for the study of the genetic and cellular properties of autism via these effects ${ }^{16}$.

Secondly, it is known that the data obtained by 3D tissue culture studies in recent years are much more realistic and more accurate due to their ability to better reflect the in vivo environment compared to 2D cell culture studies. The iPSCbased models also provide all these advantages attributed to 3D tissue culture studies. Thus, iPSC models not only enable the examination of molecular interactions and the fate of cells, but also provide the possibility to make investigations within the context of more complex systems and biochemical processes ${ }^{17}$. Due to the electrophysiological, gene expression, and other cell-based quantitative studies that can be performed on iPSC models, efforts to develop comprehensive models for autism, which have so far been slow in progress, can gain momentum ${ }^{18}$.

Thirdly, studies with iPSCs obtained by differentiating the easily accessible somatic cells of humans provide certain advantages over data collection from animal experiments. Since it is not possible to access the nerve cells of individuals with autism, autism investigations into the nervous system components such as neurons and glial cells have so far been performed on mice. However, it is known that mouse models generated by genetic modifications or exposure to viral infections do not completely reflect the microenvironment of autism in humans. For this reason, studies on the induced nerve cells formed from the somatic cells of individuals with autism and control participants will finally enable access to more realistic data that depicts the nervous system components of autism more accurately, as compared to data obtained from the nervous system studies on mouse models ${ }^{18}$. RETT syndrome is used as a genetic model of autism in some studies. Marchetto and colleagues took the fibroblast cells of RETT patients and obtained iPSCs from these cells and using $\mathrm{x}$-inactivation, they created neurons from these iPSCs ${ }^{19}$. They found that the neurons they created via this process from the RETT patients had fewer synapses, smaller neuronal soma, electrophysiological defects, and differences in calcium signaling compared to neurons created from the iPSCs of the control group ${ }^{19}$. The methods used in this study provide superiority over other models for the diagnosis, drug screening, and creation of personalized treatment for neurodevelopmental disorders such as autism.

Given these qualities of iPSCs, it is evident that they can offer new possibilities for understanding and treating autism ${ }^{20}$.

\section{iPSC-Based Treatment Approaches for Autism}

Another domain of utilization for iPSC-derived human neuron cells is in drug screening studies. Darville and colleagues used iPSC-derived neurons from patients with with autism who have SHANK3 deficiency to evaluate the effectiveness of different therapeutic compounds ${ }^{21}$. In this study, the investigation of the effect of 202 different compounds on correcting the dysfunctional expression of SHANK3 gene was made possible by iPSC-derived neurons. This method demonstrated the effectiveness of Lithium, which was then administered to a patient as treatment, and a year later, a promising decrease was observed in the severity of autism symptoms in this patient ${ }^{21}$. According to these findings, it can be said that iPSC-derived neurons may provide a novel cellular model to develop personal and targeted therapeutic approaches for individuals with autism with different etiologies 
such as SHANK3 deficiency and other known or yet to be discovered etiologies for the disorder.

One way that iPSC-derived neurons can be used for the creation of individualized treatments for autism is the following. Dental stem cells that can easily be obtained from the milk teeth of children with autism can be redifferentiated into an induced pluripotent state and iPSC-derived neurons can be created for each child with autism. Then, individual impairments and problems can be detected in these neurons, and personalized treatments that target those specific impairments can be generated $^{22}$. In developing these individualized therapies, pharmaceutical compounds can be tested on iPSC-derived neurons generated from the cells of the individual with autism for their corrective functions via the method of Darville and colleagues described above.

In another study, iPSCs were used with a different approach. iPSCs were generated from human exfoliated dedidous theeth (SHED). Dental stem cells of autism patients and control groups were re-programmed using Sendai virus. Then, they were transferred on matrigel on the fifth day. Subsequently, neuronal cells and astrocytes were obtained via adding necessary stimulating factors to the medium for each plate. Neurons derived from the individuals with autism showed significant reductions in the expression of synaptic genes, protein levels, and levels of glutamate release compared to the control group. In the co-culture experiments conducted in this study, ASD-derived astrocytes were put together with control-derived neurons, and control-derived astrocytes were put together with ASD-derived neurons. Co-culture findings revealed that ASDderived astrocytes created impairments in the neuronal morphology of control-derived neurons, and control-derived astrocytes improved the morphological and synaptic problems observed in neurons derived from the autism group ${ }^{23}$. In this study, iPSCs enabled the examination of the effects of different types of obtained nervous system cells on each other. Thus, iPSCs played an important role in establishing the formative role of astrocyte defects in the generation of neuronal differences in autism.

\section{Conclusion}

Induced pluripotent stem cells (iPSCs) offer promising opportunities to understand and treat autism, which is a neurodevelopmental difference with multiple genetic and environmental causes and still many unknowns.

iPSC-based models have the potential to guide and expedite scientific discoveries by making it possible and easy to work on real human autism nerve cells. These would be the iPSC-derived nerve cells generated from the somatic cells obtained from individuals with autism. This method can accelerate efforts to reach a more complete understanding of autism by providing easier, more animal-friendly, more economical, more practical, $3 \mathrm{D}$, and more accurate disease modelling in vitro.

Autism has different etiologies and is characterized as a spectrum disorder where the causative impairments and characteristics of affected individuals vary from person to person. For these reasons, the generation of iPSC-derived neurons from somatic cells of individuals with autism hold the potential to enable the testing of different therapeutic substances for corrective effects that are likely to differ from one individual with autism to the next.

Developed from cells that are easily obtained from individuals with autism, iPSCs that have a unique epigenetic memory and 3D modeling possibilities seem to be paving the way for developing personalized treatments for and reaching a better understanding of autism, which will hopefully be achieved in the near future by scientists making the most of all these advantages that iPSCs offer. 


\section{REFERENCES}

1- American Psychiatric Association. Diagnostic and statistical manual of mental disorders (DSM-5®). American Psychiatric Pub, 2013.

2- Baio J, Wiggins L, Christensen DL, Maenner MJ, Daniels J, Warren Z... Durkin MS. Prevalence of autism spectrum disorder among children aged 8 years-Autism and Developmental Disabilities Monitoring Network, 11 Sites, United States, 2014. MMWR Surveill Summ 2018; 67(6): 1-23.

3- Karaşahin T. Embriyonik Kök Hücreler. Erciyes Üniv Vet Fak Derg 2012; 9(1):6571.

4- İskender B, Canatan H. Uyarılmış pluripotent Kök Hücreler ve Hücre Tedavisi. JCEI 2013; 4(4): 550-561.

5- Avcilar H, Saraymen B, Özturan OÖ, Köker MY. Embriyonik Kök Hücreler ve Uyarılmış Pluripotent Kök Hücreler. Asthma Allergy Immunol 2017; 15:1-6.

6- Ateş U. Kök Hücreyi Tanıyalım. FNG \& Bilim Tip Transplantasyon Dergisi 2016; 1(1):19-28.

7- Takahashi K, Tanabe K, Ohnuki M, Narita M, Ichisaka T, Tomoda K, Yamanaka S. Induction of pluripotent stem cells from adult human fibroblasts by defined factors. Cell 2007; 131(5): 861-872.

8- Kimbrel EA \& Lanza R. Current status of pluripotent stem cells: moving the first therapies to the clinic. Nat Rev Drug Discov 2015; 14(10): 681-692.

9- Liu GH, Ding Z, Belmonte JCI. iPSC technology to study human aging and aging-related disorders. Current Opin Cell Biol 2012; 24(6): 765-774.

10- Paşca SP, Portmann T, Voineagu I, Yazawa M, Shcheglovitov A, Paşca AM... Bernstein JA. Using iPSC-derived neurons to uncover cellular phenotypes associated with Timothy syndrome. Nat Med 2011; 17(12):1657-1662.

11- Habela CW, Song H, Ming GL. Modeling synaptogenesis in schizophrenia and autism using human iPSC derived neurons. Moll Cell Neurosci 2016; 73: 52-62.

12- Vitrac A, Cloëz-Tayarani I. Induced pluripotent stem cells as a tool to study brain circuits in autism-related disorders. Stem Cell Res Ther 2018; 9(1): 226.

13- Acab A, Muotri AR. The use of induced pluripotent stem cell technology to advance autism research and treatment. Neurotherapeutics 2015; 12(3), 534-545.

14- Malkova NV, Collin ZY, Hsiao EY, Moore MJ, Patterson PH. Maternal immune activation yields offspring displaying mouse versions of the three core symptoms of autism. Brain Behav Immun 2012;26(4):607-16.

15- McFarlane HG, Kusek GK, Yang M, Phoenix JL, Bolivar VJ, Crawley JN. Autism-like behavioral phenotypes in BTBR T+tf/J mice. Genes Brain Behav 2008;7(2):152-63.

16- Connacher RJ, DiCicco-Bloom E, Millonig JH. Using Human Induced Neural Precursor Cells to Define Early Neurodevelopmental Defects in Syndromic and Idiopathic Autism. Current Pharmacology Reports 2018;4(6): 422-35.

17- Cocks G, Curran S, Gami P, Uwanogho D, Jeffries AR, Kathuria A, Steckler T, et al. The utility of patient specific induced pluripotent stem cells for the modelling of Autistic Spectrum Disorders. Psychopharmacology 2014;231(6): 1079-88.

18- Nestor MW, Phillips AW, Artimovich E, Nestor JE, Hussman JP, Blatt GJ. Human inducible pluripotent stem cells and autism spectrum disorder: Emerging technologies. Autism Res 2016; 9(5): 513-35.

19- Marchetto MC, Carromeu C, Acab A, Yu $\mathrm{D}$, Yeo GW, Mu Y, Muotri AR, et al. A model for neural development and treatment of Rett syndrome using human induced pluripotent stem cells. Cell 2010;143(4): 527-39. 
20- St. Clair D, Johnstone M. Using mouse transgenic and human stem cell technologies to model genetic mutations associated with schizophrenia and autism. Philos Trans R Soc Lond B Biol Sci 2018; 373(1742): 20170037.

21- Darville H, Poulet, A, Rodet-Amsellem F, Chatrousse L, Pernelle J, Boissart C, Cogé, F, et al. Human pluripotent stem cell-derived cortical neurons for high throughput medication screening in autism: a proof of concept study in SHANK3 haploinsufficiency syndrome. EBioMedicine 2016; 9: 293305.

22- Freitas BC, Trujillo CA, Carromeu C, Yusupova M, Herai RH, Muotri AR. Stem cells and modeling of autism spectrum disorders. Exp Neurol 2014; 260: 33-43.

23- Russo FB, Freitas BC, Pignatari GC, Fernandes IR, Sebat J, Muotri AR, Beltrão-Braga PCB. Modeling the interplay between neurons and astrocytes in autism using human induced pluripotent stem cells. Biol Psychiatry 2018; 83(7): 569-78. 